\title{
The Importance of Establishing a New Counterterrorism Unit at Local Level: Combining Different Perspectives in Policing
}

\author{
Ahmet Eker, PhD \\ Turkish National Police, Trabzon, Turkey \\ Ersan Ozkan, PhD \\ Turkish National Police, Hatay, Turkey
}

doi: 10.19044/esj.2016.v12n11p219 URL:http://dx.doi.org/10.19044/esj.2016.v12n11p219

\begin{abstract}
The number of terrorism related attacks and deaths of innocent people as a result of those terrorist assaults have been increasing. This was despite the huge amount of budget devoted towards fighting against terrorism by the governments. One of the reasons for being insufficient to reduce the number of terrorist attacks is the limited involvement of the local police agencies in the fight against terrorism. Most of them do not have separate terrorism units and are not full-time police officers. Those agencies which have separate units assign only four or less officers. As a result, their ability to get information on terrorism related activities and the level of information sharing with the federal and national agencies is very limited. It is suggested in this paper that each local police agency should establish a separate terrorism unit and assign sufficient number of full-time police officers. These officers and managers should be trained by national experts. Officers in these units should develop mutual trust with different groups that have diverse political and religious backgrounds. A strong relationship and cooperation should also be developed with other local and national agencies. In addition, each local police agency should prepare contingency plans prior to any attack.
\end{abstract}

Keywords: Terrorism, terrorist attack, lone-wolf attack, local police, intelligence sharing

\section{Introduction}

Media, politics, and the general public have devoted enormous fear and consideration on terrorism after the brutal attack of 9/11 within the border of the United States. It has been claimed that this brutal attack "represents a new era in world politics marked by the increased threat of 
violence from non-state actors. Indeed, the $21^{\text {st }}$ Century terrorism has changed the landscape of both national and international security." Moreover, these "non-state actors" has started to attack not only government officials, but also innocent civilian as well (Aly, 2015: 85). As a result, the fight against terrorism and terrorists has become one of the most important issues in all countries. This is because with globalization, a crime committed in different continents, can affect people living in other continents. Thus, the most obvious example of this can be seen in the context of terrorism and terrorist offenses.

Due to poverty and political negativity experienced in a country, another country and its citizens in different continent can become the target of terrorists. How many of the pilots of $9 / 11$ was a U.S. citizen? Why do they choose to target the United States? More recently, why do terrorists kill innocent people in France and Belgium? Why did they kill innocent people with whom they do not have a common history or past? Therefore, we may ask and raise these several types of questions. In short, no one and no country regarding the geographical location or the political structure, is safe from this type of crime and criminals. One day, terror/terrorists could knock on everybody's door. So, what should be done in this situation to stop terrorist's attacks? Of course, although individuals and societies have a lot to contribute, the bulk of the responsibilities are resting on the shoulder of the government officials. Hence, they must be prepared at all times prior to any terrorist attack.

Firstly, clarifying the definition of terrorism is very important in understanding the nature of this brutal crime type. The definition of terrorism is very controversial according to Bruce Hoffman. However, he claimed that "it is not only individual agencies within the same governmental apparatus that cannot agree on a single definition of terrorism. Experts and other long-established scholars in the field are equally incapable of reaching a consensus. In the first edition of his magisterial survey, 'Political Terrorism: A Research Guide,' Alex Schmid devoted more than a hundred pages in examining more than a hundred different definitions of terrorism. This is in an effort to discover a broad acceptable, reasonably, and comprehensive explication of the word. Four years and after a second edition later, Schmid was no closer to the goal of his quest. Therefore, he conceded in the first sentence of the revised volume that the "search for an adequate definition is still on." Walter Laqueur despaired in defining terrorism in both editions of his monumental work on the subject. Thus, he maintained that it is neither possible to do so nor worthwhile to make the attempt” (Hoffman, 2006: 34).

Aly agrees with the above arguments and claims that "there is no internationally accepted and unitary definition of terrorism". Instead of 
proposing a new definition, she prefers focusing on the fundamental features of different definitions. According to her approach, "terrorism uses violence; terrorism targets non-combatants; terrorism is intended to influence, intimidate or coerce; terrorism is motivated by political, social, or ideological objectives; and terrorism creates a state of terror and fear" (Aly, 2015: 86).

Beyond all these discussions, United Nations' definition of terror will be referred in this article. As it defines: "criminal acts intended or calculated to provoke a state of terror in the public, a group of persons, or particular persons for political purposes which are in any circumstance unjustifiable; and whatever the considerations of a political, philosophical, ideological, racial, ethnic, religious, or any other nature that may be invoked to justify them” (UN, 1994).

Statistical data in the forthcoming sections indicate that terror incidents are steadily increasing in the world. Therefore, officials should take extra measures, such as establishing new units at the local level. Also, these measures should not be seen as an additional cost. In reality, although local police officers should have active role in the fight against terrorism, they do not have enough equipment and training in this context. Moreover, most of the local police agencies do not have terror units. Thus, they dedicate insufficient number of police officers for this task. For example, only 16 percent of the local police in the U.S. have an independent terror unit (Reaves, 2015).

Subsequently, the roles of the local police agencies in the fight against terrorism will be the main focus of this paper. Although this article will use examples from the U.S., our suggestion are not limited to a single country. Instead, we will try to make general successions that will be useful to officials from all countries. Therefore, from the example of the United States, we will present an outline to clarify how the most burner type of offense - terrorism - can be handled and combated. After a satisfactory view of the increasing terrorist incidents in the world and in the United States, internal and external challenges that local police agencies should overcome will also be addressed. Finally, concrete suggestions for preparing local police agencies prior to terrorist attacks and practical policy recommendations will be presented.

Based on the review of the below examined researches, authors of this article claim that in order to conduct effective struggle against terrorism, local police agencies should give serious support, even in this context. Therefore, they should build new terror units and make provisions for more manpower. 


\section{Prevalence of Terrorist Attacks}

Preventing terrorist attacks have been very critical in recent years. Hence, this is because of the number of attacks and destructive effects of these brutal attacks which have increased. According to the 2015 Global Terrorism Index Highlights, not only less developed countries but also several developed western countries have been suffering from terrorism. Thus, this was despite the fact that a huge amount of budget (52,9 billion U.S. dollar) was devoted to preventing terrorist attacks only in 2014. This latest terrorism index presents that the numbers of terrorist attacks and casualties have been increasing dramatically since 2000 as shown in Table 1. Consequently, "there have been more than 61,000 terrorist attacks, killing more than 140,000 people since 2000” (pg.2).

Table 1: Terrorist Attacks between 2000 and 2014

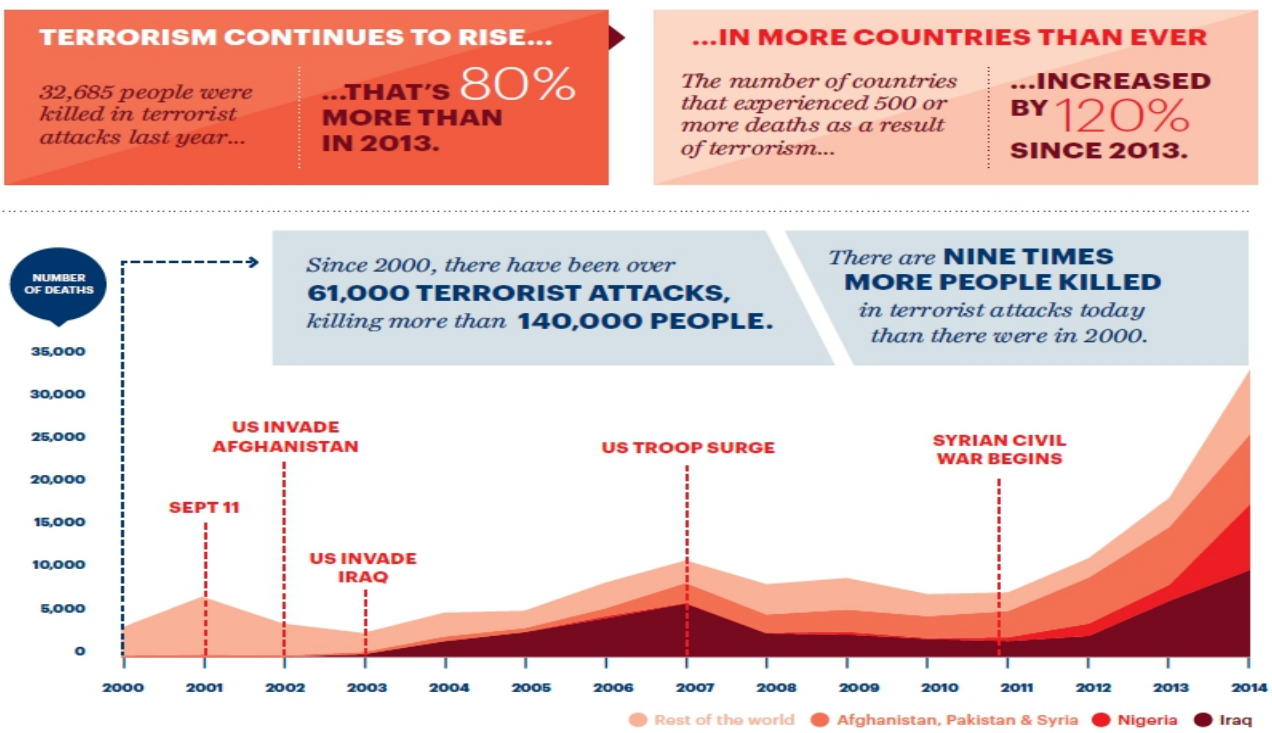

Source: The 2015 Global Terrorism Index Highlights, (pg.2).

Moreover, 93 countries had experienced at least one terrorist attack only in 2014, 13,370 incidents occurred worldwide, and 32,685 people died as a result of these incidents. The casualties in 2014 have increased by 80 percent since 2013 according to the 2015 Global Terrorism Index.

Worse than this, the number of countries that experience massive deaths caused by terrorist attacks has increased dramatically in 2014. According to the results of the 2015 Global Terrorism Index, "the number of countries that experienced 500 or more deaths as a result of terrorism, had increased by $120 \%$ since 2013" (p. 2). Most of the deaths were caused by the attacks of Boko Haram and ISIL. For instance, in 2014, ISIL carried out 1,071 terrorist attacks. However, they killed 6,073 people and injured 5,799 of them. Unfortunately, ISIL killed 2,672 (44\% of all deaths) innocent 
civilians who were not combating (Global Terrorism Index, 2015). Moreover, ISIL has "conducted or inspired nearly 75 terrorist attacks in 20 countries other than Iraq and Syria, where its carnage has taken a much deadlier toll. Those attacks outside Iraq and Syria have killed at least 1,280 people, and have injured more than 1,770 others" (Sanchez et al., 2016).

Table 2: Deaths from terrorism in 2014 for western countries*

\begin{tabular}{|c|c|c|c|c|c|}
\hline COUNTRY & DEATHS & ATTACKS & COUNTRY & DEATHS & ATtaCks \\
\hline United States & 18 & 19 & Germany & 0 & 12 \\
\hline Australia & 4 & 7 & Italy & 0 & 7 \\
\hline Canada & 4 & 2 & Sweden & 0 & 6 \\
\hline Belgium & 4 & 1 & Cyprus & 0 & 4 \\
\hline Kosovo & 2 & 4 & $\begin{array}{l}\text { Bosnia and } \\
\text { Hernegovina }\end{array}$ & 0 & 3 \\
\hline Austria & 2 & 1 & Macedonia & 0 & 3 \\
\hline France & 1 & 11 & Spain & o & 3 \\
\hline Crech Republic & 1 & 3 & Bulgaria & 0 & 1 \\
\hline Albania & 1 & 2 & Hungary & 0 & 1 \\
\hline $\begin{array}{l}\text { United } \\
\text { Kingdom }\end{array}$ & o & 102 & Iceland & 0 & 1 \\
\hline Irekand & O & 30 & Netherlands & 0 & 1 \\
\hline Greece & o & 26 & & & \\
\hline
\end{tabular}

*Source: The 2015 Global Terrorism Index (pg.51).

The U.S. has not experienced many brutal terrorist attacks prior to 2000 even though they had been threatened several times. For example, "according to the FBI, 12 terrorist attacks occurred in the United States in 1993; only 4 in 1992; 5 in 1991; 7 in 1990; 4 in 1989; 9 in 1987; and 25 in 1986. Moreover, until the 1993 bombing of New York's World Trade Center, where six persons died, no one had been killed in a terrorist incident in the United States ever since1986. Nevertheless, the United States is not immune to terrorism from within its own borders. A variety of ethnic/émigré groups, purely indigenous terrorist organizations, and foreign terrorist groups are committed to the use of violence in the pursuit of their political objectives" (Riley \& Hoffman, 2005: 13). Unfortunately, the projection of Riley and Hoffman had come true with the tragic event of barbarically planned 9/11 attack. In addition, it has killed thousands of innocent people "within own borders of the United States" (pg. 13).

However, not only the U.S. suffers from terrorism, but also several western countries as presented in Table 2. According to the 2015 Global Terrorism Index, in the 15 years between 2000 and 2014, there were 3,659 deaths from terrorism in the West (pg.50). Also, in the U.S., there were 250 
terrorist attacks in the above mentioned 23 western countries, and 37 innocent people were killed only in 2014 (pg. 51).

A recent report of European Law Enforcement Agency (EUROPOL), presented in Table 3, displays that although the number of terrorist attacks had decreased between 2012 and 2013, there was an increase in 2014 (European Union Report, 2015). Most of these199 terrorism related attacks "in the EU were carried out by separatist groups in 2014" (pg. 6). European countries also have huge concerns regarding the religiously motivated terrorists who "travel to and from conflict zones, which has enhanced the capabilities terrorist individuals”. Thus, 774 individuals were arrested in EU countries only in 2014. This excessive number of terrorists who were arrested "for religiously inspired terrorist activities - which were mainly concentrated in France, Belgium, Spain, Austria, Bulgaria, the Netherlands, and Germany - underlines the threat” (pg. 6). Moreover, recent ruthless attacks in France and Belgium signal that there are vital and immediate threats for European countries. Orders of spokesman of ISIL terrorist organization make those threats more robust. This is because ISIL has "replaced al-Qaida as the biggest threat for attacks in the West through lone wolf tactics”. Therefore, “on 22 September 2014, the spokesperson of ISIL called for sympathizers to engage in attacks in Western countries" (Global Terrorism Index, 2015: 51).

Table 3: Number of failed, foiled, or completed attacks; and number of arrested suspects from 2012 to 2014*

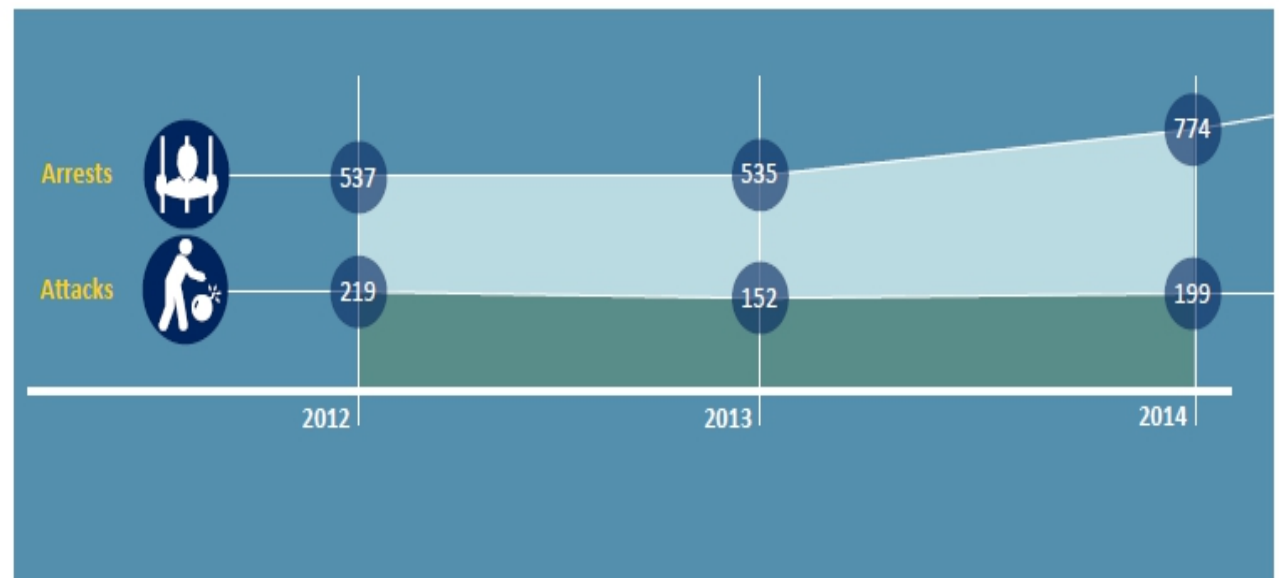

*Source: European Union Terrorism Situation and Trend Report 2015 (pg. 8).

As mentioned above, most of the terrorist attacks in western countries were conducted by the terrorists. Hence, some of these attacks were related to ISIL, while others were "home-grown" terrorists. These terrorists mostly followed "lone wolf tactics". Hence, lone wolf terrorists are individuals or a small number of individuals who commit an attack in 
support of a group, movement, or ideology without material assistance or orders from such group. For example, 164 innocent people were killed in western countries as a result of terrorists attacks categorized as "lone wolf attacks” (Global Terrorism Index, 2015, pg.54).

\section{Motives behind the Terrorist Attacks}

When people talk about terrorism, they usually believe that the main reason for terrorist's attacks is religious based motivation. This assumption is true but only partly. Researchers found that the major reason for terrorist attacks is the perception of the individuals who think that western countries have hostility against their countries. Thus, they "retaliate against countries participating in military activities in conflict zones" (European Union Report, 2015: 6). Additionally, scholars found that $67 \%$ of the all casualties in western states were caused by individuals characterized as lone wolf terrorists. Thus, their motivation was political. Interestingly, religious beliefs "was not the major motivation for lone wolf terrorist attacks in 2014" (Global Terrorism Index, 2015: 58).

Table 4: Number of deaths from lone wolf terrorists in the west by motivation, 2006_2014* Politically motivated terrorists acts account for the most number of deaths in the West. Lone wolf attacks motivated by Islamic fundamentalism accounted for 19 per cent of total deaths.

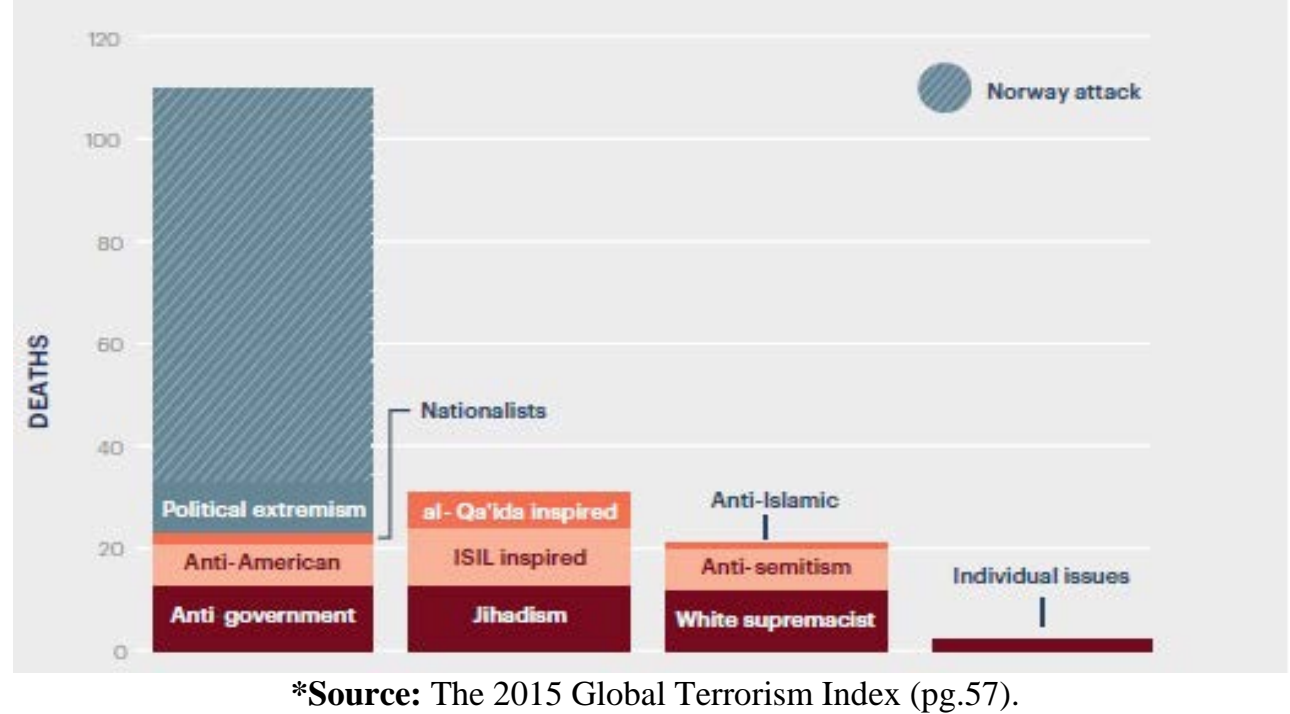

As can be seen from the table below, there are 11 different sources of motivation for terrorist's attacks. Most of the fatalities (164 innocent people) were caused by the terrorists who were politically motivated. Political extremists killed 87 people. Also, 13 individuals were killed due to antigovernment reasons. "White supremacists killed 12, anti-semites killed 8, 
while people motivated by anti-Islamic attitudes killed 1. Furthermore, ISIL inspired attacks was the motivation behind five attacks. Hence, it resulted to 11 deaths. Al-Qa'ida inspired 14 incidents and killed 7. Overall, this accounts for 19 percent of total deaths from lone wolf terrorism in the West” (Global Terrorism Index, 2015: 56).

These different sources of terrorist attacks make prevention efforts more difficult. This is because it would be easier if only one group of individuals carry out terrorists attacks. In this case, police agencies should monitor different groups of people who have diverse sources of motivation. Therefore, monitoring and controlling all these diverse groups can only be possible if national and local police agencies should devote more manpower, budget, and technical equipment in the war against terrorism. In this context, local agencies should create or establish new unit "anti-terror unit" to deal with these motives.

\section{Role of Local LEAs in Fighting Terrorism}

Dealing with terrorism - "particularly terrorism that involves the use of Weapons of Mass Destruction” - is a new issue for local LEAs (Alexander, 2005: 13). Majorly, it has been seen as the job of federal agencies, especially FBI and the military. First reason for this perception is the educational level of the local law enforcement officers. However, they are not educated well enough to deal with terrorism. Also, they really have limited knowledge to handle these kinds of situations. The second reason is the shortage of staff and resources. However, police chiefs simply do not want to "waste" their limited resources with a job that is being handled by national and federal agencies, such as the FBI (Riley et al., 2006).

Consequently, Vice President George H. Bush tried to change this perception of local LEAs. This he did by mentioning the possible threats of terrorist attacks with WMD on American people and critical places for the first time in 1986. However, he gave "a warning order to local agencies that they would serve several important functions in dealing with such incidents" (Riley et al., 2006: 13). Moreover, the catastrophic incident of 9/11 attack has skyrocketed the measures taken not only by federal agencies, but also by the State and the local law enforcement agencies (LEA). This is aimed in preventing any possible domestic terrorist attacks. Much more emphasis was given to local LEA because it was claimed that September 11 attack could have been prevented if the federal agencies had shared their information. For example, President Bush mentioned the importance of information sharing with local LEAs in FBI Headquarter in February 2003. He stated: "All across the country, we'll be able to tie our [Federal] information to local information banks so that the front line of terror becomes activated and real, and those are the local law enforcement officials” (Alexander, 2005: 16). 
In opposition to the above statements and struggles, only 16 percent of the LEAs have established a "specialized terrorism units" in 2002. Hence, this was according to a RAND survey that examined the preparedness of police agencies (Riley et al., 2006: 9). Unfortunately, as was recently released, the "2013 Law Enforcement Management and Administrative Statistics" (LEMAS) report found that no improvements have been done during eleven years since 2002. As seen in Table 2, most of the larger departments (71\%) have more than 100 sworn officers who tend to have a separate terrorism units. Hence, these departments have approximately 33 full time officers. Unfortunately, only 16 percent of small departments (99 officers or less) have a separate terrorism unit and they assign only 4 police officers full time. However, 32 percent of these small departments have impaired driving units, $28 \%$ have domestic violence, $20 \%$ have gangs units, and 39 percent have child abuse units (Reaves, 2015).

Table 5: Personnel designated to perform special operational tasks in local police departments by the size of department, 2013

Departments employing 100 officers or more

\begin{tabular}{|c|c|c|c|c|c|c|}
\hline Problem or task & Total & $\begin{array}{c}\text { Personnel } \\
\text { assigned full } \\
\text { time to special }\end{array}$ & $\begin{array}{c}\text { Other } \\
\text { designated } \\
\text { personnel }\end{array}$ & Total & $\begin{array}{c}\text { Personnel } \\
\text { assigned full } \\
\text { time to }\end{array}$ & $\begin{array}{c}\text { Other } \\
\text { designated } \\
\text { personnel }\end{array}$ \\
\hline Bias/hate crime & $38 \%$ & $10 \%$ & $28 \%$ & $15 \%$ & $5 \%$ & $10 \%$ \\
\hline Child abuse & 90 & 61 & 29 & 39 & 11 & 29 \\
\hline Cyber crime & 76 & 39 & 36 & 26 & 6 & 20 \\
\hline Domestic violence & 81 & 54 & 28 & 28 & 8 & 20 \\
\hline Gangs & 83 & 55 & 28 & 20 & 6 & 14 \\
\hline Human trafficking & 42 & 15 & 27 & 11 & 3 & 8 \\
\hline Impaired driving & 75 & 39 & 36 & 32 & 9 & 23 \\
\hline Juvenile crime & 82 & 59 & 23 & 34 & 11 & 23 \\
\hline Victim assistance & 62 & 37 & 26 & 21 & 6 & 14 \\
\hline Bomb/explosive disposal & 41 & 15 & 26 & 6 & 2 & 4 \\
\hline Fugitives/warrants & 68 & 41 & 27 & 24 & 7 & 17 \\
\hline Re-entry surveillance & 21 & 7 & 14 & 8 & 2 & 6 \\
\hline Tactical operations(SWAT) & 95 & 30 & 65 & 31 & 5 & 26 \\
\hline Terrorism/homeland security & 71 & 33 & 37 & 16 & 4 & 12 \\
\hline Source Reaves, (2015). & & & & \\
\hline
\end{tabular}

Source: Reaves, (2015). Local Police Departments, 2013: Personnel, Policies, and Practices (Two tables at pages 9 and 16 were combined).

Similarly, as presented in Table 6, most of the information gathering and sharing had been done by state level agencies. On the contrary, local police departments did not dedicate much time and personnel to gather information on terrorist groups (Reaves, 2015). For example, as mentioned in Table 4, most of the terrorist attacks had been conducted due to political reasons. However, it is unfortunate to notice that only $17 \%$ of the local police gathered and shared information on right-wing terrorists. Worse than 
this, although religiously motivated terrorism has been increasing all over the world, only $3 \%$ of local police agencies focus on these terrorist groups. The major reason for this deficiency is the perception of local police agencies. They assume that counterterrorism intelligence gathering and analysis tend to occur as part of a larger criminal intelligence unit. Thus, terrorist threats did not lead to large-scale changes in the organizational structure of most local police departments. Nevertheless, most of the states and local police agencies have prepared "threat assessments" (Riley et al., 2006).

Table 6: State vs. Local Law Enforcement Agencies Focus on Terrorism

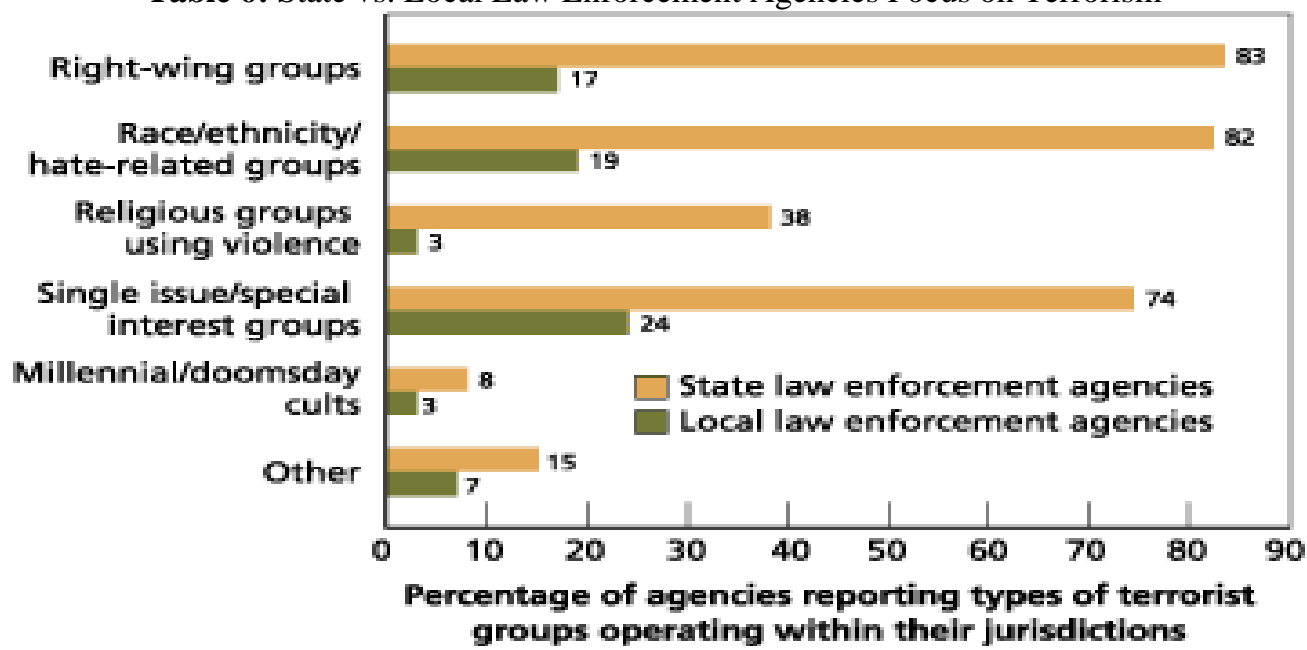

Source: Riley et al. (2006). Think Locally, Act Nationally: Police Efforts in Fighting Terrorism Need Greater Federal Leadership.

Consequently, all the information provided above indicates that local police agencies do not focus on terrorism. This is because they assume that they are incompetent to deal with this complex crime. Thus, they rely on state and federal agencies. However, previous experiences of terrorist attacks prove that local police agencies can contribute a lot to state and federal agencies. Therefore, the reasons why local law enforcement agencies should have separate terrorism unit and full time police officers will be presented in the next section.

\section{Reasons for a New Counterterrorism Unit}

If RAND survey found that only 16 percent of the local police agencies have separate terrorism units, then why do we claim that all local police departments should have a counterterrorism unit? The first reason is the presence of real danger of terrorist attacks on each city. Thus, the above mentioned experts' reports show that 9/11 attack proves that no city is immune from terrorist attacks. Therefore, each local police agency should 
have a specialized unit to fight effectively with terrorists. By this, the newly established department will increase its efficiency and effectiveness because specialized units can fight with a specific problem better (Katz, 2001).

Moreover, local police officers are more capable of preventing terrorist attacks. "Local police can prevent terrorism in areas under their purview. Therefore, opportunities abound for police officers to "scan, analyze, respond, and assess". Using this methodology can be useful in providing early warning of impending attacks. For instance, armed with the knowledge of the methods by which terrorist conduct pre-attack surveillance of target areas, police officers can identify potential terrorist targets in their geographic area of responsibility. In addition, they can determine the locations where terrorists might conduct reconnaissance" (Alexander, 2005: 14). Since local police officers know the area and the people living within their jurisdiction better, they have more opportunity than federal agents to observe and arrest terrorists. Even in a traffic control, a patrol officer can detect suspicious activities and persons (Alexander, 2005).

The second reason is the national trends in having counterterrorism units and Joint Terrorism Task Forces with Federal agencies. Most of the big cities, such as New York have established terrorism units. Federal agencies, such as FBI and the U.S. Marshals Service have established Joint Terrorism Task Forces including local police agencies in 56 FBI field offices. Justice Department has also established 93 Anti-Terrorism Task Forces "to integrate the communications and activities of local, state, and federal law enforcement agencies” (Hill, 2002: 24). Therefore, a new unit should be established to work with federal agencies. Otherwise, local agencies cannot have cooperation and information sharing with other agencies. They have no alternative, but to follow this national trend.

Final external reason is the demand from the sovereigns, such as mayor, city council, other criminal justice agencies, and the general public. According to institutional theory, not all of the changes in police agencies are based on rational calculations. Police agencies generally accept policies and structures because of environmental pressures. Through this way, police maintains its legitimacy in the eyes of the sovereigns (Katz, 2001). Therefore, this unit is needed by mayor, city council, and the general public. This is because of the increased terrorist threats and attacks. They also want this unit because there is an undeniable terrorism fear among the public after 9/11 incident. According to "democracy at work thesis", local police agencies should respond to the will of the public in a democratic country (Beckett, 1997: 4). 


\section{External Issues}

Consequently, all local LEAs should consider important issues which are very essential in order to have an efficient counterterrorism unit. Since terrorism cannot be prevented by only the efforts of a local police force, they should have good relationships with politicians, local public, local media, federal agencies, and other local agencies, especially neighboring agencies. The first issue is the satisfaction of the sovereigns with the capability of the new unit. Institutional theorists claimed that the legitimacy of a unit depends on the acceptance of the sovereigns. Since the request for a counterterrorism generally come from them, agencies do not need to convince them about the importance of the new unit. Hence, they must satisfy sovereigns about the capacity of this new unit. Therefore, chief of police and head of counterterrorism unit should inform sovereigns (mayor, city council, media members, public, and interest groups) on a regular basis (Katz, 2001). They should inform them about the potential threats, about the measures taken by the local police, cooperation with other agencies, and the needs of the new unit.

A second important external issue is having a good relationship and communication with other national agencies. Since terrorism is not same as a regular crime, and generally has roots outside the target country, local police departments have no capacity to reach outside their jurisdictions. Therefore, they should have a good coordination with national or other federal agencies that are fighting against terrorism. For example, FBI has been the dominant agency in fighting terrorism for many years in the U.S. The Joint Terrorism task Forces have been established in 56 FBI field offices. These JTTFs include liaison officers from "the U.S Marshals Service, the U.S. Department of State's Diplomatic Security Service, the Bureau of Alcohol Tobacco and Firearms, the Immigration and Naturalization Service, the Secret Service, and local agencies”. Furthermore, Department of Justice also established "93 Anti-Terrorism Task Forces in each U.S. Attorney's district -to integrate the communications and activities of local, state, and federal law enforcement” (Hill, 2002: 24). Therefore, local police agencies should select a liaison officer who has necessary skills. These skills include good communication skills and common sense to work with these agencies harmoniously.

Another issue is having good communication with neighboring local police agencies and national guards. This is because in a possible terrorist attack, each city police force may need support from others. Establishing a good communication and information sharing with these agencies is not only essential to prevent a terrorist attack before it happens, but is also very important to arrest the terrorists after it happens. Therefore, they should establish a radio channel that can be used by all neighboring law 
enforcement agencies. Furthermore, they should share their databases and all relevant information with them (Hill, 2002).

The fourth issue is establishing a good coordination with local agencies, such as fire department, health department, hospitals, and transportation department. This coordination is very necessary during and after a terrorist attack (Riley \& Hoffman, 1995). Unless local LEAs have a good coordination with these agencies, they will have chaos during an attack. As Istanbul Police Department does, they should establish a "crisis center" within their city. Each department should send a member to this center. Prior to a terrorist attack, they should establish this center, and determine the responsibilities of each agency clearly. The Mayor or the Chief of Police should be in charge of this center. However, he should direct the departments from one location to another during a terrorist attack.

Other issue that local police departments should consider carefully is having good relationships with city legislators, judges, and prosecutors. Since terrorism is a relatively new issue, there is no clear rule and regulations about how to handle a terrorist case. Most of the police officers do not have a clear sense of the procedures regarding terror investigations (Dean et al., 2007). More especially, the intelligence officers have little guidance. Therefore, they should be careful not to violate the civil rights because "the courts - the federal courts in particular-will continue to strike the balance between privacy and civil liberties on one hand, and national security on the other hand” (Riley et al., 2005:13). Therefore, in order to prevent human right violations, and protect police officers from being responsible for violation of civil liberties, they should clarify the laws, rules, and regulations by working together with legislators, judges, and prosecutors.

Fifth and the final external issue that local LEAs should consider is having good relationship with the local people. This communication is important for two aspects. Firstly, they should maintain good relationship and trust with their law-abiding citizens. Thus, this makes it easier for the local people to support them before and during a terrorist attack. For example, they can inform local police officers if they observe any suspicious activity. Therefore, local police should inform the public about the possible danger of terrorist attacks, how they can help local police, and about their new department (Alexander, 2005). The second aspect is in having good relationships with minorities, religious groups, and political parties. Since most of the local police agencies have community-policing officers ("7 in 10 local police departments; 9 in 10 departments serving a population of 25,000 or more”) (Reaves, 2015: 8), these officers can establish a good relationship and have a mutual understanding with those groups. This will be a win-win situation because these groups also do not want their youth to engage in 
terrorist activities. Through this, the police can gain their support. Also, the police will be able to ask them to report any radical activities. Local police can have regular meetings with community leaders with the aim of preventing terrorism, radicalism, and extremism.

\section{Internal Issues}

Legitimacy of a new department is not only important outside the organization, but is also important within the organization. Unlike other units, this new counterterrorism unit needs absolute support from other departments, such as patrols, intelligence division, crime analyzing unit, community policing unit, and SWAT teams. Without their help, this new unit will have limited power similar to any other outsider agencies. As mentioned above, the advantages of having local units come from the support of other units. This is based on the fact that these units can fully control their jurisdictions. Thus, they share information with new terrorism unit if their supports are gained (Alexander, 2005).

Therefore, based on the 20-year policing and administrative experiences of the authors of this paper, each police department should be very careful during the establishment of this new unit. To prevent the rivalry and resistance from other departments, they should not give the impression that this new unit is superior to and does more critical job than other units. Secondly, they can also prevent or at least decrease resistance from other units by performing joint training programs. During these programs, the head of the counterterrorism unit should make explicit statements about how important the role of other units is. Thus, this would be a good tactic in gaining the support of others. This is because they will be convinced that the full credit will not go to one unit alone.

Again, based on our ample experiences, another tactic to accelerate the acceptance of the new unit by other departments can be the selection of the staff. The first aspect of the selection process looks to officers. However, we suggest that each unit should select officers who have experience or education in terrorism issues. If they do not have police officers endowed with these abilities, which is very common in most of the local police agencies, they should select one officer from each department. This tactic will accelerate the acceptance of the new unit by other departments. Hence, this is because selected officers will be liaison officers naturally. Most importantly, each unit should select those officers according to their criteria. They should not let the head of other divisions to determine who those officers should be. This is because based on our two-decade long administrative experience, the head of other divisions generally select the most unwanted, problematic, and least skillful persons. This kind of assignment will result to more problems rather than increasing the 
partnership. Therefore, they should select persons who are liked within their departments. This, however, makes it possible for them to serve as liaison officers between his/her old and new units. By this, they can establish and maintain a good coordination within their organizations.

The second aspect of selection process looks at the head of this new counterterrorism unit. Since this new unit needs support from other departments, the head of this unit should have equal or higher rank with other units' chiefs. Police organizations have paramilitary hierarchy. Therefore, rank is very important during the relations. Based on our experiences, if a person with a rank of lieutenant is assigned as the head of this new unit whereas chiefs of other units are majors, this person will most probably have difficulties during communications. Therefore, we suggest that, depending on the rank structure of the whole department, a highranking officer should be assigned as the head of this new unit.

Another important internal issue that should be considered is the location of this new unit. Three major issues should be considered while determining the locations of this unit. Firstly, because of the sensitivity and urgency of terrorist attacks, chief of this unit should not be far from the office of the chief of police. Secondly, since intelligence is the most effective tool to fight terrorism, these two units should work hand in hand. Finally, mapping the locations of the critical infrastructures and determining the locations of the minorities and possible suspicious extremist is very important in fighting terrorism. Therefore, we suggest that the best place for this unit should be as close as possible to these units.

Finally, the role of the police unions should be considered while these new units are being established. Since police unions are very active and strong in many developed countries, each police department should reach an agreement with them especially regarding the working conditions of police officers. This is because court decisions and enacted statutes by the state and local legislative branches force department management to realize that the union exists. In addition, the unions will help to protect the rights of officers. Therefore, good relations with unions should be built as a necessary skill for successful management (Nowicki et al., 1991).

\section{Preparedness for a Terrorist Attack}

The question arises whether or not creating new unit is enough to handle terrorism attack. To deal with brutal attacks, law enforcement should be ready. In addition, contingency plans should be prepared, operation capacity should be improved, and officers should be trained. 


\section{Developing Contingency Plans}

Since none of the cities is immune from terrorist attacks, every one of them should be prepared prior to any attack. Also, they should prepare contingency plans. "Contingency planning is one major route through which organizations can judge the adequacy of their preparedness against terrorism. Indeed, the purpose of contingency planning is to identify available resources and identify ways those resources can be formed into an operational plan. Oftentimes, one major element of contingency planning is determining which organizations will bear the responsibility of the various aspects of addressing a terrorist crisis" (Riley \& Hoffman, 2005: 28). Therefore, each unit should make a "vulnerability assessment" of the critical infrastructures located at their jurisdiction, such as power plants, dams, water sources, and big buildings. These units should exactly prepare a list of these points. Also, they should know the security level of each one of them. Consequently, security levels of them should be increased. Moreover, these units should also inform other federal and neighboring local agencies about their critical infrastructures. Furthermore, since newly established units will not have too much experience in terrorism, they should submit these plans to federal and national agencies, such as Homeland Security and FBI to evaluate their plans and make complementary advices if necessary (Riley \& Hoffman, 2005). The last issue that should be considered is preparing the necessary equipment for handling a terrorist attack. Again, preparation should be completed prior to any attack by consulting more experienced agencies.

\section{Operational Capacity}

All police departments should also improve their local police and other agencies' response capacity “during” a terrorist attack. The best way to improve this capacity will be by making the role of each agency to be very clear previously (Riley et al., 2005). As mentioned above, they should establish an emergency center that is composed with liaison officers from each department, such as, health, police, and transportation. Each agency should know who would be in charge on behalf of the mayor during an emergency situation. This center also should have a good communication with national and federal joint task forces. Moreover, they should make field exercises together with all these entities to improve their practice and cooperation. As being the major agency in fighting with terrorism, local police force should also clarify the responsibility and role of each of its departments, such as terrorism unit, SWAT team, traffic unit, and etc. during a terrorist assault (Riley et al., 2005). 


\section{Training}

Another critical issue while establishing a terrorism unit is training of its officers and managers. This is aimed in improving their ability of handling crisis situation such as a massive terrorist attack. Since most of the local police forces are not satisfactorily educated on handling terrorist attacks, such as biological and chemical attacks, they should increase their organizational skills by training the staffs (Kaplan, 2006). "In particular, two types of training, anti-terrorism and counterterrorism, are relevant when considering preparedness issues. Anti-terrorism is defined as measures taken to prevent terrorism acts from occurring. Anti-terrorism, thus, primarily consists of physical security measures designed to thwart the execution of terrorist acts. In contrast, counter-terrorism involves monitoring and analyzing terrorist threats, as well as responding to terrorist acts once they have been committed” (Riley \& Hoffman, 2005: 38).

Since almost all of the local LEAs do not have any experts on this issue, they should send their officers to national and federal agencies, such as HLS, FBI, and state training facilities (Riley et al., 2005). For example, FBI director, Mueller, mentioned in a Congressional Hearing that FBI has trained almost 27.000 police officers (2013). These training activities should continue. Most especially, local police managers and police officers should be trained by federal or national agencies in order to understand the scope of the threat of terrorism and to acquire the necessary skills. Moreover, law enforcement agencies should also be sure that other local agencies, such as fire and health department, are prepared for a terrorist attack. For example, health department should train its staff on how to handle the situation after a biological attack. They should have joint training exercises on a regular basis. Since they do not have much experience, for the first year, these agencies should make several joint exercises to improve their practical skills and to clarify the role of each agency. In the following years, the number can be decreased to two or one time a year as most of the local agencies do (Riley \& Hoffman, 2005).

\section{Conclusion and Discussion}

In evaluation of the above discussions, the most important deficit is the lack of involvement of local police agencies in the fight against terrorism. Unfortunately, LEMAS report indicates that less than one in every five local police departments has a separate terrorism unit. Moreover, those agencies having separate terrorism units dedicated only to 4 police officers who are full time. More interestingly, even the barbaric 9/11 attack did not affect local police agencies' level's focus on terrorist groups. As a result of low level of dedication, focus, and limited manpower, their information 
gathering and sharing activities are very insufficient. Hence, this was mentioned in the above table.

Governments all over the world, but especially developed western countries, have been allocating enormous amount of money to prevent terrorist attacks. However, various numbers of terrorist attacks have been increasing contrary to the expectations and dedicated huge budget. These increased numbers should warn policy makers and law enforcement agencies about some ongoing incorrect policies. In the light of above researches, we claim that officials should not only focus on what they are doing, but should also focus on "how" they are doing it.

Based on the above discussion and more than 20-year policing experiences of both authors, we claim that effective war against terrorism is impossible without involvement and the full focus on local police agencies for three reasons. Firstly, federal, state, and national agencies cannot be familiar with the local residents and groups as do local police agencies. Local police officers, who patrol their jurisdiction day by day, encounter local residents and establish strong contacts. None of the "outsider" officers can have those chances in a local area. Therefore, local people who naturally monitor each house and street of their locations share every suspicion activity "unofficially and promptly" with known local officers.

Secondly, federal, state and national agencies cannot dedicate their resources and valuable time (!) to the local issues as local police agencies do. As a reflection of human nature, local police officers evaluate their jurisdiction as their own home. Thus, they dedicate their full attention on any single issue. On the other hand, national level agencies have to deal with state level problems. Thus, they always have more important duties than local problems (!). This is not a fictitious claim, but it is a fact based on practical experiences.

Thirdly, even though only limited number of local police agencies has separate terrorism units and assigned full time officers, almost all of them assign police officers to deal with terrorism besides other duties. However, giving two or three different duties to one officer reduces his success and motivation. Again, this is based on our personal management experience. For example, one of the authors of this paper runs a police department. However, a Crime Prevention Unit, under his command, should deal with terrorism, juvenile delinquency, public disturbances, fugitives, and index crimes. Police officers in that unit mostly deal with index crimes and juvenile delinquency since these crime types are committed more frequently and they attract the attention of the media, sovereigns, and governor more than other crime types. Moreover, as mentioned above, there are 11 different groups who carry out terrorist attacks. Without assigning full time officers, it would be impossible to adequately monitor all these groups. Thus, this 
makes it difficult to become an expert on each terrorist group. Additionally, in order to have good relations with minorities, different religious and political groups requires dedication of long times. As such, only full time assigned officers can accomplish that.

Again, based on our experience, police agencies suffer from shortage of manpower and budget. Thus, they mostly focus on visible crimes and discount invisible and victimless crimes, such as prostitution, bribery, smuggling of goods, white color crimes, and so on. For example, one of the authors of this paper witnessed a conversation between a Chief of City Police and a Chief of Human Trafficking Unit while he was working in a country. The Chief of Human Trafficking Unit asked for more manpower to deal with human trafficking and prostitution more effectively. The response was tragic: the Chief of City Police said that "he would assign more officers to traffic unit because the governor of the city gives more importance to parking problems”. As seen in this real case, several police chiefs do not allocate their limited resources for problems which are not visible and imminent. Unfortunately, we argue that terrorism is also evaluated as an invisible crime until it happens. Hence, this may sound unrealistic to the general public since terrorist attacks kill thousands of people, but unfortunately it is the reality. We argue that because of this unfortunate reason, the percentage of having separate terrorism units at local police agencies have not changed in the U.S. since 2002.

However, although local police managers do not give more considerations to terrorist threats, the above statistics and everyday terrorist attacks warn that threat of terrorism is imminent and brutal. Therefore, we suggest that each local police agency should have a separate terrorism unit and should increase the capacity of their new units. Thus, this is possible by preparing their city forces because none of the cities are immune from terrorist attacks. More importantly, police chiefs should be convinced and forced, if necessary, by local and national actors. Additionally, as it happened for the community policing in the U.S., local police agencies should be motivated in establishing terrorism units via monetary supports given by national governments.

However, although we insist on the importance of local police agencies' increased involvement in the fight against terrorism, we neither deny nor depreciate the experience and technical capacities of the federal and national level agencies. We suggest that local police agencies should dedicate more efforts to fight against terrorism. They should closely work with federal and national police and demand support from them in terms of training and information sharing.

Additionally, we suggest that each local police agency should increase its capacity by gaining support from both internal and external 
entities. In doing so, local police agencies should consider important internal issues, such as resistance from other departments. They should also have strong public support by informing and working together with local residents. Local police agencies should give them the impression that they are not seen as terrorist by police forces. On the other hand, the police should follow only the bad guys who are destroying the credibility of these groups. Moreover, having mutual trust with them is vital for the prevention of terrorist attacks and for arresting the suspects after attacks. Local police agencies have far more opportunities than national agencies to establish the required relationships with these groups.

In sum, it is difficult to establish a new unit in imposing it. Therefore, external and internal factors are obstacles to be considered and should be acted upon in a stable manner. To increase local police' efficiency in the fight against terrorism, we must follow some steps in a systematic way: contingency plans should be developed, operational capacity must be enhanced, and training should be updated. Therefore, these efforts increase the legitimacy of the local police agencies.

\section{References:}

Alexander, B. C. (2005). Strategies to Integrate America's Local Police Agencies into Domestic Counterterrorism.Retrieved from, http://www.strategicstudiesinstitute.army.mil/pdffiles/ksil178.pdf

Aly,A. (2015).Terrorism: Historical and Contemporary Issues Global Terrorism Index. Retrieved on 06 April 2016 from

http://economicsandpeace.org/wp-content/uploads/2015/11/GlobalTerrorism-Index-2015.pdf

Beckett, Katherine (1997). Making Crime Pay: Law and Order in Contemporary American Politics.New York: Oxford University Press.

Berg, M., Dean, G., Gottschalk, P., \&Karisen, J. (2008).Police management roles as determinants of knowledge sharing attitude in criminal investigations.International Journal of Public Sector Management, 21(3), 271-284.

Dean, G., Holgerson, S., \& Gottschalk, P. (2007). Knowledge management in law enforcement: Knowledge views for patrolling police officers. International Journal of Police Science \& Management,10(1), 76-88.

European Union Terrorism Situation and Trend Report (2015). Retrieved on 06 April 2016 from

https://www.europol.europa.eu/content/european-union-terrorism-situationand-trend-report-2015

Global Terrorism Index (2015).Retrieved from http://economicsandpeace.org/wp-content/uploads/2015/11/GlobalTerrorism-Index-2015.pdf 
Hill, E. (2002). Counterterrorism Information Sharing With Other Federal Agencies and With State and Local Governments and the Private Sector.Retrieved from http://www.fas.org/irp/congress/2002_hr/100102hill.pdf Hoffman, B.(2006). Inside Terrorism,(2 ed.), Columbia University Press. Kaplan, E (2006). Examining Counterterrorism Culture.Retrieved from http://www.cfr.org/publication/11922/examining_counterterrorism_culture.h tml\#1

Katz, C. M. (2001). The Establishment of a Police gang Unit: An Examination of Organizational and Environmental Factors. Criminology.Vol. 39 No. 1.

Luen, T.W., \& Al-Hawamdeh, S. (2001). Knowledge management in the public sector: Principles and practices in police work. Journal of Information Science, 27(5), 311.

Miller, E. (2015). "Overview: Terrorism in 2014". START College Park, MD. August.Retrieved from http://www.start.umd.edu/pubs/START_GTD_OverviewofTerrorism2014_ Aug2015. pdf.

Mueller, R. S. (2013). Congressional Hearing before the Senate Select Committee on Intelligence of the United States Senate. Retrieved on 07 April 2016 from https://www.fbi.gov/news/testimony/war-on-terrorism

Nowicki, E. D., Skyes, W. G., Eisenberg, T. (1991).Human Resource Management.InLocal Government Police Management edited by Geller, W. A. Washington: International City/County Management Association.

Reaves, B. A. (2015).Local Police Departments, 2013: Personnel, Policies, and Practices.Retrieved on 05 March 2016 from

http://www.bjs.gov/content/pub/pdf/lpd13ppp.pdf

Riley, K. J., Treverton, G. F., Wilson, J. M., and Davis L. M. (2005) State and Local Intelligence in the War on Terrorism. Retrieved from, http://www.rand.org/pubs/monographs/2005/RAND_MG394.sum.pdf

Riley, K. J. and Hoffman, B. (2005) Domestic Terrorism: A National Assessment of State and Local Preparedness. Retrieved from http://www.rand.org/pubs/monograph_reports/2005/MR505.pdf

Riley, K. J., Wilson, J. M., Treverton, G. F., and Raymond B. (2006) Think Locally, Act Nationally; Police Efforts in Fighting Terrorism Need Greater Federal Leadership. Retrieved from

http://www.rand.org/publications/randreview/issues/spring2006/police.html Sanchez, R., Lister, T., Bixler, M.,O'Key, S., Hogenmiller, M. and Tawfeeq, M. (2016). ISIS goes global: 75 attacks in 20 countries have killed 1,280 people. CNN International Retrieved on 06 April 2016 from 
http://edition.cnn.com/2015/12/17/world/mapping-isis-attacks-around-theworld/

United Nations,(1994).Declaration on Measures to Eliminate International Terrorism.Retrieved on 25 march 2016 from http://www.un.org/documents/ga/res/49/a49r060.htm

\section{Annex 1: Motives for terrorist attacks}

\begin{tabular}{|c|c|}
\hline SUBCATEGORY & DEFINITION \\
\hline Anti-Iskmic & $\begin{array}{l}\text { The target chosen purely because of their association with Islam. This includes attacks on mosques } \\
\text { and retaliation attacks. }\end{array}$ \\
\hline Anti-semitism & Motivated by a prejudice against Jews. \\
\hline White supremacist & $\begin{array}{l}\text { Motivated by a racist worldview and could include identification with views of the Nagi's } \\
\text { and the KKK. }\end{array}$ \\
\hline Individual issues & $\begin{array}{l}\text { The attack is due to issues specific to an individual. This may involve a desire to gain attention, a } \\
\text { particular dogma or actions relating to particular delusions stemming from the influence of drugs } \\
\text { or a mental illness. }\end{array}$ \\
\hline Al-Qa'ida inspired & $\begin{array}{l}\text { Influenoed by al-Qaida and undertook an attack without al-Qa'ida's involvement to further the } \\
\text { ideology of the group. }\end{array}$ \\
\hline ISIL inspired & $\begin{array}{l}\text { Influenoed by ISIL and undertook an attack without ISIL's involvement to further the ideology of } \\
\text { the group. }\end{array}$ \\
\hline Jihadism & $\begin{array}{l}\text { Inspired by Islamic fundamentalism to engage in violence. The attacker may be inspired by a } \\
\text { particular Islamist group, but is more focused on violent jihadism. }\end{array}$ \\
\hline Anti-American & $\begin{array}{l}\text { Attack undertaken to express opposition to specific foreign policies or other actions by the United } \\
\text { States and its allies. }\end{array}$ \\
\hline Anti-government & $\begin{array}{l}\text { Anti-authoritarian motives for their attack including opposition towards the police, tax office, post } \\
\text { office or other instruments of government. Anarchists are included in this category. }\end{array}$ \\
\hline Nationalists & The attacker was inspired by nationalism. This includes separatists. \\
\hline Polítical extremism & $\begin{array}{l}\text { Action undertaken to promote a particular political viewpoint. This may include stances of } \\
\text { immigration, abortion, LGBT rights or any other view. It is extremist by definition due to the } \\
\text { violence involved. }\end{array}$ \\
\hline
\end{tabular}

Source: The 2015 Global Terrorism Index (pg. 56). 